\title{
Martonyi János
}

\section{Európai identitás - Nyitni vagy bezárkózni}

\section{European Identity - To Open Up or Close Down}

Az európai integrációs folyamat kulturális dimenziója jelentősen le van maradva az integráció másik két dimenziója, az elörehaladott és sikeres gazdasági integráció és a mérsékelt szintū politikai integráció mögött. Az egyéni és közösségi identitás fogalmának elemzése után az írás arra a következtetésre jut, hogy a kollektív identitások legerōsebb, elsődleges formája a nemzeti identitás. Az európai identitás ehhez képest másodlagos, de szintén történelmi örökségre épül, mindenekelött a zsidó kulturális hagyományban gyökerezö kereszténységre, az antik kultúrára és a római jogra. További érdekes kérdés, hogy van-e az európai identitásnak egy közép-európai változata, és ha igen, melyek Európa ezen részének a történelem formálta sajátosságai. E történelmet az agressziv külső hatalmak elleni védekező háborúk jellemezték, ez eredményezte a kereszténység és a nemzeti identitás közötti szoros kapcsolatot és az Európához való erős kötődést. A kontinens kulturális örökségének, a Geschichtsraumnak, a Kulturraumnak és a Wertegemeinschaftnak az elismerése és megerôsítése elengedhetetlen feltétele az európai integrációs folyamat sikeres folytatásának.

Kulcsszavak: kulturális dimenzió, közösség, identitás, nemzet, kereszténység, antik kultúra, római jog, Közép-Európa

The essay focuses on the cultural dimension of the European integration process, a dimension, which is lagging behind the other two dimensions, such as the economic - most advanced and successful - and the political - moderately developed - of the integration. Starting with the general notion of identity, individual and collective, it comes to the conclusion that the most important form of collective identity is the national identity. European identity, while only secondary to the national one, is also based upon a common historic heritage, primarily on the Christianity rooted in the Judaeo-Christian tradition, the antique culture as well as the Roman law. Another interesting question is, whether there is a special Central-European version of European identity and what are the characteristics of this part of Europe, again formed and shaped by history, such as defensive wars 
against the invasions of aggressive outside powers, and for this reason a very close link between the national identity and Christianity, as well as the strong attachment to the "espace de civilisation" of Europe. The recognition and the strengthening of the cultural heritage of the continent as a Geschichtsraum, a Kulturraum as well as a Wertegemeinschaft is an essential prerequisite for the successful continuation of the European integration process.

Keywords: cultural dimension, community, identity, nation, Christianity, Antique culture, Roman law, Central-Europe

Az 1950-es években felerősödtek egy európai politikai közösség megteremtésére irányuló törekvések. Megszületett az európai védelmi közösség és az európai politikai közösség létrehozására vonatkozó javaslat, amelyet akkor - sokak meglepetésére - a francia nemzetgyülés leszavazott. Ez adta a gondolatot elsősorban Robert Schumannak, Jean Monnet-nak és másoknak, hogy ebben a helyzetben a gazdasági integrációt kell napirendre tűzni. Ennek előzményeként már létezett az Európai Szén- és Acélközösség, megvolt tehát a modell, hogyan lehet - legalábbis egy meghatározott szektorban - gazdasági integrációt létrehozni. Létezett már az az intézményrendszer is, amelyet az Európai Szén- és Acélközösséget létrehozó párizsi szerződés megteremtett, és amely a lényegét illetően ma is változatlan. Elindult tehát a gazdasági integráció, amelybe később bekapcsolódott a politikai unió megteremtésére irányuló folyamat is. Lényeges intézményi változásokra került sor, amelyek az egész intézményrendszert fokozatosan bővítették, módosították, alakították, mélyítették: Maastricht, Amszterdam, Nizza, majd az alkotmányozó szerződés nyomán a lisszaboni szerződés, amelyek nem hoztak létre új, önálló alapszerződést, hanem módosították a római szerződést.

A gazdasági integráció és az intézményi fejlődés fő vonulatai mellett kevesebb figyelmet kapott, hogy ennek az egész folyamatnak mi az alapja. Mire épül, miért indult el az integrációs folyamat? Miért gondolják sokan, hogy meg kell őrizni, amit elértünk? Miért gondoljuk nagyon sokan, hogy mindezt folyamatosan reformálni és tökéletesíteni is kell? Bizonyos dolgokban tovább kell lépni az integráció útján. Bizonyos dolgokban nagyobb mérsékletet kell tanúsítani, netán vissza is kell lépni. Tehát egy sok szempontú, szelektív megközelítés alapján továbbra is gondolkodunk azon, hogyan vigyük tovább ezt a folyamatot. De a folyamat lényegét lehet, hogy nem mindig értjük. Az európai integráció lényege nem feltétlenül a materiális szférában, nem a politikákban, nem a gazdaságban, még nem is feltétlenül a geopolitikában keresendő, hanem ennél valamivel mélyebben: a fejünkben, a legszélesebb értelemben vett kultúrában. Azt kell tehát keresnünk és megtalálnunk, hogy mi Európa lényege, azt a kérdést kell feltennünk, hogy van-e európai identitás, és ha van európai identitás, akkor mi annak a lényege. Ezek az európai integrációs folyamattal kapcsolatos legfontosabb kérdések. Fontosabbak, mint a gazdasági integráció, amelynek jelentőségét nem becsüljük le, már csak azért sem, mert az európai integrációs folyamatnak messze ez a legsikeresebb dimenziója. De a világban nem mindent a gazdaság határoz meg. Volt és van olyan ideológia, amely szerint minden a gazdaságban gyökerezik, mindent a gazdaság határoz meg. Ez nem így van. Nem biztos, hogy a vallásháborúk hátterében mindig a gazdasági vagy akár a politikai vagy a hatalmi tényezők játszanak szerepet. Vannak más, sokkal fontosabb 
tényezők, amelyek meghatározzák az egyének és közösségek életét és általában a történelmet. Az európai integráció esetében is ezt a szellemi, kulturális dimenziót kell megközelítenünk és megértenünk.

Az identitás a legkülönbözőbb tudományágak által tárgyalt téma. Eredendően egy antropológiai fogalom, amely megragadta a pszichológia, majd a szociológia érdeklődését is. Az identitás fogalma a jogban is lényeges. A nemzetközi magánjognak például fontos kérdése, hogy hogyan határozzuk meg az ember személyes jogát. Mit tekintünk az egyes ember szempontjából meghatározónak? Annak az országnak a jogát tekintjük-e személyes jogának, amelyiknek az állampolgára, vagy annak az országnak a jogát, amelyikben letelepedett? A jogrendszerek egy része az állampolgársághoz, más részük - az angolszász országok joga - pedig az állandó letelepedés szándékával elfoglalt lakóhelyhez, a domicíliumhoz kapcsolja a személyes jogot. Vannak, akiknek a terület a fontosabb, és vannak, akik az állampolgári hovatartozást tartják meghatározónak. Az sem mindegy, hogy az állampolgárságot mire alapítjuk, mit tekintünk a legfontosabb kapcsolatnak az ember és az állam között. Vannak, akik számára ez a kapcsolat döntően a lakóhely, annak az államnak a területe, ahol az ember él, és vannak, akik szerint az állampolgárságot az határozza meg, hogy valakinek a felmenői, a szülei, nagyszülei stb. melyik ország állampolgárai voltak. Ha pedig ez így van, akkor fölmerül a kérdés, hogy ha valakinek a szülei vagy éppen a nagyszülei magyar állampolgárok voltak, akkor egyetlen döntő körülménynek kell-e azt tekinteni, hogy ezeknek az embereknek a felmenői Szabadkán vagy Szegeden, Nagyváradon vagy Debrecenben, Kassán vagy Miskolcon éltek. Ez vezetett el a határon túli magyarok magyar állampolgárságának az elismeréséhez, illetőleg ahhoz a lehetőséghez, hogy ezek az emberek a felmenőikre hivatkozva magyar állampolgárságot nyerjenek. Ezek is az identitással összefüggő kérdések.

$\mathrm{Az}$ identitás akkor lett igazán érdekes, amikor bevonult a politikába. Az identitás egyéni téren is fölvet problémákat, az egyén identitása is izgalmas kérdés. Az egyének identitása általában többszörös, tehát kevés az olyan ember, aki egyetlen identitást hordoz, tehát egyetlenegy közösséghez tartozik. Mi magyarok vagyunk, a magyar nemzethez mint közösséghez tartozunk. Ugyanakkor persze lehetünk vallási közösségnek is a tagjai, ami nagyon lényeges szerepet tölthet be az életünkben. Lehetünk hinduisták, buddhisták, muszlimok, zsidók, keresztények, katolikusok vagy protestánsok, ezek mind fontos közösségek. Tartozhatunk egy politikai párthoz, egy politikai mozgalomhoz. Ez is fontos lehet, sajnos esetenként túlságosan is fontos szerepet töltött be bizonyos emberek életében. Ami komoly veszélyeket rejthet, az a kizárólagos identitás. Erre elég sok példa van a történelemben. Ljudmila Ulickaja regényében szerepel az a szovjet fiatal, akinek annyira kizárólagos volt a bolsevik párttal való azonosulása, a bolsevik identitása, hogy az NKVD-nél az édesapját jelentette fel. Ha valakinek több identitása lehet, akkor ebből az is következik, hogy az identitások ütközhetnek. A görög tragédiákban is ezt írták meg, de nagyon sok mai példa is van. Az aradi vértanúk úgy döntöttek, hogy ők nem osztrák tisztek, hanem magyar hazafiak, átálltak a magyar honvédseregbe, és ezért az életükkel fizettek. Van egy újabb példa is, amely még élesebb konfliktust jelez az identitások között. Volt egy magyar politikus, aki egész fiatal korától kezdve részt vett a kommunista mozgalomban, meggyőződéses kommunista lett, a Szovjetunióban élt, ennek minden következményével. Azután 1956-ban a nép hangja miniszterelnökké emelte, de ő még a kommunista párt tagja volt. Egy ponton el kellett döntenie, hogy 
melyik identitása - a magyar vagy a kommunista - az első. Ezt kétszer döntötte el. Először eldöntötte 1956. október 28-án, amikor parancsot adott a harcok megszüntetésére, majd arra, hogy be kell vonni a forradalmárokat és a nemzetőrséget a hadseregbe, és egy új forradalmi koalíciós kormányt kell létrehozni. Ez volt az első döntése, átállt a szabadságharcosokhoz. Erre még azt is lehetne mondani, hogy ez a kényszerítő körülmények hatására is történt. De volt egy másik döntése is, amikor elmentek hozzá Romániába, hogy jöjjön haza, írjon alá néhány papírt, nem lesz bántódása, talán még egy kisebb állást is kap. Ô akkor átgondolta ezt a dolgot, és annak biztos tudatában, hogy ki fogják végezni, nem írta alá ezt a papírt. Ütközött az eredeti kommunista identitása a nemzeti identitásával, a magyarságával. És ez az ember úgy döntött, hogy számára a magyar identitás, a magyar nemzethez tartozás fontosabb. Így lett mártír.

$\mathrm{Az}$ egyéni identitás változhat is. Az identitásválasztás szabad, ami azt is jelenti, hogy az ember az élete során akár meg is változtathatja az identitását. Ismerjük a költőtől, hogy „szívet cseréljen az, aki hazát cserél”, tehát nem olyan egyszerű hazát cserélni, vagy nemzethez tartozást cserélni, de erre is vannak példák.

Ami igazán érdekessé teszi jelenleg ezt a témát, az nem annyira az egyéni, személyes identitás, hanem a közösségi identitás. A közösségi identitásnál az első kérdés az, hogy egyáltalán van-e ilyen. Nagyon sokan úgy látják, hogy minden egyes egyénnek van hovatartozása, van önazonossága, de a közösségeket ilyen tulajdonsággal, identitással felruházni nem lehet. Itt indul el a politikai vita, amely ma az egész világon univerzális, globális méretekben folyik. Vannak, akik a közösségi identitást veszélyesnek ítélik, és az identitáspolitikát törzsi jellegűnek, nativistának vagy még rosszabbnak nevezik. A közösségi identitásnak mindig a túlzásaira hivatkoznak, mert erre is vannak példák a történelemben, és erre építik a közösségi identitással szembeni bizalmatlanságot és politikai ellenszenvet. Közösségi identitás márpedig van, tehát a közösségnek is van önazonossága, saját lényege, ami a közösséghez tartozó egyének identitásából áll össze. Az egyén ebből a közösségből, a közösség pedig az egyénektől nyeri az identitását. A nemzet fogalma, értelme feltételezi a nemzetnek mint közösségnek az identitását, amely nem köthető pusztán a területhez. Nem biztos, hogy a nemzeti identitás, a nemzethez való tartozás azonos azzal, hogy a nemzet tagja melyik állam területén él. Magyarország esetében a nemzet és az állam határai, következésképpen a nemzet és az állam fogalma is eltérnek egymástól. Szükségünk van tehát egy önálló nemzetfogalomra. A kulturális nemzetfogalom a 19. századi francia vallástörténészhez és filozófushoz, Ernest Renanhoz nyúlik vissza, aki De Gaulle elnöknek is kedvenc szerzője volt.

A nemzet ezek szerint a történelemben gyökerező lelki, szellemi, nyelvi kulturális közösség, amit kétségtelenül befolyásolnak területi tényezők, államhatárok is, de a nemzeti közösség nincs feltétlenül területhez kötve, és nem azonosítható az államhoz tartozással. Ha ennek a kulturális közösségnek elismerjük az identitását, akkor ennek a nemzetnek, nemzeti közösségnek jogai is kell hogy legyenek. Így jutunk el mind alkotmányjogi, mind pedig nemzetközi jogi szempontból a közösségi jogok, tehát a kollektív jogok kategóriájához, amelyről ma is éles viták folynak. A nemzeti kisebbségek kollektív jogait mi a nemzetközi egyezményekben általában nem tudjuk elfogadtatni, az európai jogi instrumentumokban is csak az egyéni jogok jelennek meg nemzeti kisebbségekhez tartozó személyek jogaiként. 
Miért fontos a közösségi identitás? Először is azért, mert így tudjuk felépíteni a legfontosabb közösségi identitást, tehát a nemzeti identitást. Ez az identitás nem kizárólagos, de a legtöbb európai ember számára elsődleges. Európában tehát az elsődleges, a legfontosabb közösségi identitás a nemzeti önazonosság. Ha az európai identitást erősíteni akarjuk, ennek elengedhetetlen feltétele nemcsak a közösségi identitás elismerése, hanem a nyelvi, kulturális, lelki közösségekre épülő nemzeti identitásnak az elfogadása, elismerése és erősítése. Ez vezet egy sokszínű, de létező európai identitáshoz.

Ha nem tudjuk elfogadni a közösségi, ezen belül a nemzeti identitás létét, akkor nem fogjuk tudni megérteni az európai identitást sem. A kettő tehát összefügg, először el kell fogadnunk a nemzeti identitást mint meghatározó elsődleges hovatartozást, és ez tud elvezetni az európai identitáshoz, annak elismeréséhez és erősítéséhez.

Ha megegyeztünk abban, hogy van európai identitás, akkor a következő kérdés, hogy mi ennek az identitásnak a tartalma. A kiindulópont a sokszínűség, ez a szó szerepel a lisszaboni szerződés 3. cikkének 3. pontjában. Vita arról szólhat, hogy melyek ennek az európai identitásnak a legfontosabb elemei. 1976-ban mondta azt Helmut Kohl, hogy Európa elöször is egy Geschichtsraum - történelmi tér, egy Kulturraum - kulturális tér, és harmadikként pedig egy Wertegemeinschaft - értékközösség. Robert Schuman pedig azt mondta hetven évvel ezelőtt, hogy Európa nem más, mint egy espace de civilisation - civilizációs tér. Nem azt mondta, hogy Európa az Atlanti-óceántól - ahogyan azt annak idején Metternich mondta - Bécsig vagy - ahogyan De Gaulle mondta - az Urálig terjed, hanem azt, hogy Európa egy civilizációs tér, egy kulturális tér, tehát a lényege a kulturális identitás.

Az európai identitásról sok szó esett és esik ma is. Ha az európai identitást meg akarjuk érteni, akkor persze hasznos, ha elolvasunk történetfilozófiai műveket, de valójában a legegyszerübb, ha kimegyünk az utcára, és megnézzük, mi vesz minket körül. Mit látunk? Először is látni fogunk nagyon sok keresztet, nemcsak a templomokon, hanem a temetőkben, a közterületeken, az utakon és a legkülönbözőbb témájú alkotásokon is. Tehát az első dolog, ami egy másik bolygóról ideérkező embernek feltűnne, hogy mit jelent itt ez a kereszt, mi ennek az üzenete, a jelentése. Azután déli 12 órakor halljuk a harangszót, sőt harangozunk az ünnepeken és a temetéseken is. Kereszteket látunk és harangszót hallunk, mindez valami közösre, valami összetartozásra utal.

Mit látunk még Európában? A képtárakban és a köztereken is embereket ábrázoló szobrokat, festményeket, gyakran mezítelen emberi testet látunk. Vannak olyan civilizációk, ahol tilos az emberábrázolás, még inkább a ruhátlan emberi testnek az ábrázolása. Mi pedig évezredek óta ábrázoljuk az emberi testet. Büszkék vagyunk az emberi test szépségére, ezért ábrázoljuk. Más civilizációkban ezt nagyon szigorúan tiltják. Ez pedig az antik kultúrában gyökerezik. Nem véletlen, hogy a kereszténység után az antik gyökereket, az antik örökséget szoktuk az európai identitás másik nagyon fontos forrásaként megjelölni. Európa nem létezne a görög-római örökség, tudomány, művészetek nélkül, és ezért különösen hálásak vagyunk a reneszánsznak, mert ez az újjászületés ismét viszszahozta a mi kultúránkba, a mi identitásunkba az antik örökséget, annak minden szépségével és tudásával együtt. Nem olyan régen Macron elnök ékesszóló beszédet mondott Európáról, amelyben kifejtette, hogy igenis van európai identitás. Ennek alátámasztásaként arra hivatkozott, hogy bárhova megy, mindenhol látja a görög templomokat. 
Európában valóban vannak görög templomok, de azt Marcon elnök nem mondta, bár a Sorbonne-on mondta el ezt a híres beszédét, hogy onnan néhány száz méterre ott van a Notre-Dame, amelyet talán még a Sorbonne-ról is lehet látni. Az európai identitás egyik sarkalatos tényezője éppen a Notre-Dame és a székesegyházak jelenléte mindenütt Európában. A hangsúlyt tehát nem mindig ugyanoda tesszük, de végül is, ha egyet tudunk abban érteni, hogy van egy zsidó-keresztény hagyomány, ami ennek az espace de civilisation-nak egy kardinális eleme, akkor abban is egyet tudunk érteni, hogy igen: van egy antik örökség is. Abban is egyet tudunk érteni, hogy az európai történelemnek egy sor más mozzanata is van, ami beépült ebbe az európai identitásba. A felvilágosodás nyomán beépültek a szabadság, egyenlőség és testvériség eszméi is. És van még valami, amit Európában látunk. Láttuk a keresztet, láttuk az antik szobrokat és festményeket, és a legtöbb európai város főterén látunk egy nagy, tekintélyes épületet. Ez az épület a bíróság, az igazságszolgáltatás épülete, amely mindenütt kiemelt helyen van. Ez az az épület, ahol igazságot szolgáltatnak annak ellenére is, hogy nem mindig és nem mindenütt az igazságot szolgáltatták ezekben az épületekben. Európai civilizáció, európai kulturális tér a jog nélkül nem lenne, és ezért mondjuk, hogy Európának a harmadik legfontosabb gyökere, tényezője a jog, aminek az alapja a római jogi örökség. Így jutunk el az ismert három dombhoz. Az Akropolisz mint az antik kultúra, a Golgota mint a zsidó-keresztény hagyomány és a Capitolium mint a római jog jelképe. Valamennyi európai országnak a jogrendszere végül is a római jogból nőtt ki. Az európai országok jogrendszerének nagy többsége befogadta, átvette, recipiálta a római jogot, így tett többek között a német, francia, svájci és a magyar jog. Van olyan jogrendszer - az angol -, amelyik nem ezt tette, mégis az angol jogi nyelv használja a legtöbb latin kifejezést.

Az európai történelemben nemcsak a szuverén államiságnak, hanem az európai politikai egységnek is vannak előzményei. A területileg kijelölt határokkal rendelkező szuverén államok létrejöttét az 1648-ban megkötött vesztfáliai békéhez szoktuk kapcsolni. Ez a béke rögzítette a határokat, rögzítette, hogy elfogadjuk, hogy a határon túl más vallású emberek vannak, és egyben egyfajta - ma geopolitikainak mondott - egyensúlyt teremtünk, ami az alapja lesz annak, hogy nem indítunk újabb harminc évig tartó vallásháborút. De Európában volt római birodalom, volt később frank birodalom, azután volt Német-római Császárság, ami nem jelentett igazi politikai egységet, de mégis keretet adott Európának. És létezett az európai népek, nemzetek respublikája, nevezetesen a Respublica Christiana - Keresztény Köztársaság -, és így ismét eljutunk a kereszténységhez, az európai identitás lényegéhez. Ha elfogadjuk, hogy Európának van identitása, és ebben ez a három elem jelen van, akkor a sorrenden akár még vitatkozhatunk is, de egy dolgot ne tegyünk vitássá: a sokszínűséget és az abból fakadó toleranciát.

Ha elfogadtuk, hogy létezik európai identitás, akkor van-e közép-európai identitás is? Mert a közép-európaiságról történelmi, gazdasági, politikai értelemben nagyon sokat beszéltünk, különösen a rendszerváltozás időszakában és azt követően. Nem véletlenül hoztuk létre a Közép-európai Szabadkereskedelmi Társulást, nem véletlenül hoztuk létre a Visegrádi Együttműködést. A közép-európai gondolat tehát, amint volt rá alkalom, azonnal megjelent a közelmúlt történelmében. A közép-európai együttmüködési törekvésekkel egy kulturális összetartozást, örökséget, kulturális dimenziót fordítottunk, alakítottunk át gazdasági és politikai realitássá. Volt valami, amit a filmmúvészet, az irodalom, a költészet, általában a kultúránk már régóta hordozott, és amit 
azután - amikor megadatott a történelmi lehetőség, mert a Szovjetunió kivonult ebből a térségből - át tudtunk alakítani gazdasági és politikai valósággá.

Mi tehát a közép-európai identitás lényege? A közép-európai identitás valójában ugyanaz, mint az európai, de sűrúbben, gyorsabban és nagyobb fordulatszámmal, talán több feszültséggel. Nagyon sok nyelv, nagyon sok vallás viszonylag kis területen, még nagyobb a sokszínűség, mert hiszen Közép-Európa déli részében látunk mecseteket is. Közép-Európában még a kereszteknek is legalább két fajtája van, mert hiszen az ortodoxia is jelen van. Közép-Európában volt egészen a holokausztig a legtöbb zsinagóga. Tehát ez egy sűrűbb, intenzívebb, magasabb fordulatszámú Európa, mint Európa általában. Mondják, hogy melankolikusak vagyunk, borúlátók vagyunk. Sokszor azt is mondják, hogy humorosabbak vagyunk, mert van egy speciális humorérzékünk, amit valószínúleg a történelem alakított ki. Mondják, hogy kreatívak vagyunk, különösen mi, magyarok büszkék szoktunk lenni a Nobel-díjasainkra és a kreativitásunkra. Sokan azt is mondják, hogy egy kicsit neurotikusak vagyunk, azt is mondják, hogy komplexusaink vannak, például kisebbrendűségi komplexusunk, nyilván a történelem alakította ki ezt is. Vannak, akik azt mondják, hogy felsőbbrendűségi komplexusunk van, éppen a kisebbrendúségi miatt. Mindezen lehet vitatkozni, de az biztos, hogy létezik egy sajátos közép-európaiság.

Ami a vallási türelmet illeti, itt mondta ki az 1568-as tordai országgyúlés Európában először a vallásszabadság tételét, és hirdette meg a vallási türelem elvét, ami akkor az egész európai kontinensen példátlan volt. A közép-európaiság velünk van, és egyre erősebben előtérbe kerül. Ami a nemzeti és az európai identitást illeti, két tételt kell leszögezni. Az egyik az, hogy a közép-európai országokban a nemzeti identitás erősebben kapcsolódik a kereszténységhez, mint Nyugat-Európában. Amikor az európai alkotmányozó szerződés kidolgozására hivatott Európai Konventben vita folyt arról, hogy a szerződésben hivatkozzunk-e Európa keresztény gyökereire, a közép-európaiak többsége ezt támogatta. A hivatkozás döntően a francia ellenzés miatt nem került be az alkotmányozó szerződésbe, és így a lisszaboni szerződésbe sem. (A Preambulum csak általában utal a kulturális, vallási és nyelvi gyökerekre.)

Közép-Európát a történelem során döntően külső támadások érték. Ezek a külső támadások egyaránt fenyegették a kereszténységünket és a nemzeti identitásunkat, más szóval a puszta nemzeti létünket. Mi magyarok gyakran mondjuk, hogy a magyar történelem a túlélés története, de Bryan Cartledge, az angol történész is a „túlélés akarása”, The Will to Survive címet adta a magyar történelemről szóló könyvének. Olyan külső támadásokat kellett tehát túlélnünk, amelyek mind a kereszténységünket, mind a puszta nemzeti létünket fenyegették. Nyugat-Európában pedig a nemzetek egymással vívták komoly háborúikat: a százéves háborút az angolok a franciákkal, a harmincéves háborút németek németekkel. Mindezek egymás közötti harcok voltak, és nem jelentettek egzisztenciális veszélyt a háborúban harcoló nemzetekre és azok identitására. E háborúk tétje az volt, hogy Anglia vagy Franciaország lesz-e az erősebb hatalom, protestáns vagy katolikus lesz-e Németország, de nálunk a harc nem erről szólt, hanem arról, hogy fönnmaradunk-e nemzetként és keresztényként, vagy sem. Következésképpen fontosabb volt nekünk a kereszténység, és fontosabb volt Európa. Mert ha a török végérvényesen elfoglalja az egész országot, és egy török tartományt rendez be a teljes történelmi Magyarországon, akkor nem biztos, hogy a túlélésünk magyar nemzetként 
biztosítva lett volna. A lényeg az, hogy a mi nemzeti identitásunk elválaszthatatlanul kapcsolódott, kapcsolódik a kereszténységhez és Európához. Ezért fontosabb nekünk egyrészt a kereszténység, másrészt - és ez a második tétel - az Európához tartozás itt Közép-Európában.

Az alkotmányozó szerződést két alapító tagállam, Franciaország és Hollandia közvéleményének többsége utasította el népszavazással. Összességében nyugodtan lehet mondani, hogy Közép-Európában - elsősorban Lengyelországban és Magyarországon, tehát a két külső támadásnak legjobban kitett országban - mind a kereszténységhez való tartozás, mind az Európához való tartozás érzése lényegesen erősebb, mint a nyugat-európai országokban.

Az európai identitás harmadik eleme az említett bírósági épület: a jog. A római jogot megelőzően is voltak fontos törvények, mégis a római jog volt az első összefüggő rendszer, amely nélkül a jogi normák ma nem töltenék be azt a szerepüket, amit ma egész Európában, minden országban betöltenek.

A mitológia azt bizonyítja, hogy Európában minden valahonnan jött. Az egyiptomi civilizáció nélkül nem lett volna Kréta, Kréta nélkül nem lett volna görög kultúra, nem lett volna antik múveltség, és nem lett volna Róma. A monoteista világvallások között is sok közös elem van, az emberiség és a civilizációk beszéltek egymással, a sok ezer kilométer távolság ellenére is. A hinduizmus masszívan hatott a judaizmusra, és ezen keresztül a kereszténységre. Az iszlám sem egyedülálló, sajátos sivatagi kezdeményezés, hanem számtalan vallásból vett át elemeket. Európának van egy markáns, nagyon jól meghatározható identitása. Ugyanakkor Európa mindig is a legnyitottabb kontinens volt ezen a világon, befogadott külső hatásokat, így építette fel a dombjait. Felépítette az Akropoliszt, felépítette a Capitoliumot, a Golgotát, majd pedig ezt követően elkezdte kisugározni a hatását. Az európai civilizáció terjeszkedése nélkül a világ nem olyan lenne, mint amilyen ma. Európa nagyon sokat adott a világnak, bármennyire divatos most e civilizáció eredményeit kétségbe vonni. Apró példa, hogy az angol jog megjelent a világ kétharmadában, és jelenleg is ezek az országok mind az angol jogra építik az intézményrendszerüket. Az európai kultúra lenyomata a világban tagadhatatlan.

Európa egyrészt kapott a világtól, másrészt a kisugárzásával sokat adott a világnak. Ezt a kisugárzást most is folytatni lehet, folytatni is kell, de ehhez az kell, hogy saját magunkat rendbe hozzuk. Saját magunk legyünk tisztában saját magunkkal, a saját magában valónkkal, a saját lényegünkkel. Ez lenne az európai identitás. Más szavak is alkalmasak ennek kifejezésére, Schuman például az Európa lelke, l’âme de l’Europe kifejezést használta, mert Európának lelke is van, csak meg kell tudni találni. Ma az integrációnak ez a sarkalatos kérdése.

Az európai integrációs folyamat hetvenéves története egy döbbenetes gazdasági siker, egy politikai félsiker, de a kulturális dimenzió és ezzel az identitás kérdése valójában el lett hanyagolva, annak ellenére, hogy az alapszerződésben a kultúra nyomatékosan szerepel. Létrejött az egységes piac és - kisebb-nagyobb gondokkal, nehézségekkel - az egységes pénz is. A gazdasági integráció ma minőségi előrelépésekrôl tesz tanúbizonyságot, feltéve, hogy az újgenerációs alap elfogadást nyer, és masszív fiskális eszközöket vetünk be a monetáris politika eszközei mellett. Még akár a politikai, védelmi együttmúködés terén is elöre tudunk lépni, de az alapkérdés továbbra is az, hogy tudunk-e ennek a kulturális dimenziónak, az identitásnak egy erősebb tartalmat 
és kifejezést adni. Erre tudnánk építeni egy olyan lelki közösséget, egy olyan összetartozást, egy olyan démoszt, amelyre egy valóságos és erős politikai együttmúködés építhető. De ez hosszú folyamat, amit nem szabad erőltetni, mert erre is vannak kísérletek. Pár nappal ezelőtt meghallgatott az Európai Parlamentnek az Alkotmányügyi Bizottsága két intézményi reformelképzelés kapcsán: az egyik a Spitzenkandidat elv, a másik pedig a transznacionális lista. Én ezekkel egyébként nem értek egyet, de nem is ez a lényeg. A lényeg az, hogy ne mindig intézményi téren keressük a megoldást. És ha majd most megint lesz egy újabb nagy konferencia, ám legyen, de ne mindig azon gondolkodjunk, hogy milyen felülről kigondolt, az emberekre ráerőltetett intézményi trükkökkel próbáljuk a folyamatot elörevinni.

Az intézmények és a jogszabályok nagyon fontosak, hiszen nélkülük semmi sem múködne. De azt is látni kell, hogy az intézményi megoldásoknak korlátjaik is vannak, és vannak olyan helyzetek, amikor nem az intézményi és jogi kérdéseket kell előtérbe helyezni, nem újabb intézményi reformokon kell gondolkodni, hanem azon, hogyan tudunk tartalmat vinni a folyamatba. Erősebb tartalmat, erősebb identitást, erősebb összetartozást. A közép-európai hozzájárulás jelentősebb lehet, mint ami egyébként Közép-Európa gazdasági és politikai jelentőségéből fakad, jóllehet ezen a téren sem állnak rosszul a dolgok. Érdemes egymástól tanulnunk, és a sokszínűség csak akkor érvényesül, ha kölcsönösen képesek és készek vagyunk egymástól tanulni.

Előbb utaltam a vesztfáliai békére. Ez a béke azt mondta ki, hogy elfogadjuk, hogy vannak, akik másként gyakorolják a keresztény hitüket, mert hiszen mind a két fél keresztény volt, csak az egyik kálvinista vagy lutheránus, a másik meg katolikus. El kell fogadni és tisztelni kell egymást, és nem szabad azt hinni, hogy az egyik alacsonyabb vagy magasabb rendű, mint a másik.

A demográfia a globális vagy univerzális történelem egyik legfontosabb tényezője. Két fontos tényező formálja hosszú távon a történelmet, az egyik a demográfia, a másik pedig a technológia. Mind a kettő a kultúra függvénye, tehát „a fejben dől el”. A reprodukciós képessége, készsége egy közösségnek éppen úgy, mint a technológia. Európa demográfiailag veszít, és nem úgy tủnik, hogy ezt a demográfiai zsugorodást meg tudjuk fordítani. Ezt valamilyen módon ellensúlyozni kell. Az egyik ellensúly a közös kül- és védelmi politika és a védelmi képességek erősítése. Már az antik világban is, ha egy városállam demográfiailag gyengült, védelmi képességeinek erősítésével tudta ezt ellensúlyozni. Ehhez persze technológia és politikai elhatározás kell. Az egész folyamat eredetileg úgy indult, hogy volt egy legyöngült, szinte reménytelen helyzetben lévő Európa és két szuperhatalom, az Egyesült Államok és a Szovjetunió. A Szovjetunió ráadásul nagyon közel volt, és egyre közelebb is jött. Az Egyesült Államok segítette Európát, jelentősen hozzájárult ahhoz, hogy Európa fel tudjon emelkedni. Az sem volt egy könnyű helyzet, de végül megindult az európai integráció. Az egyik tehát a külpolitika és a védelem erősítése. A másik ellensúly pedig az identitás erősítése.

Felmerült a kínai identitás vagy kínai kultúra veszélye. Kérdés persze, hogy valójában mi a kínai identitás. Konfuciusz? Buddha? Marx? Engels? Sztálin? Mao Ce Tung? Vagy egyszerűen csak az anyagi jólét, a termelés kultusza? A gazdagság? Ha megkérdeznek egy kínai embert, hogy mit szeretne az életében elérni, százból kilencvenkilenc azt fogja mondani, hogy gazdag akar lenni. Tehát a kínai identitást nehéz meghatározni, azon kívül, hogy van egy hatalmi, gazdasági és geopolitikai expanziós törekvés. Arra 
a kérdésre, hogy Kína az európai identitást fenyegeti-e vagy sem, fennáll-e egy ideológiai, a kultúrával, az identitással kapcsolatos veszélyeztetettség, a válasz az, hogy nem. Ami itt kérdésként merül fel, az sokkal inkább a bevándorlás, és ezzel összefüggésben az iszlám. Vannak, akik az iszlámot halálos veszélynek tartják, és vannak, akik azt mondják, hogy az iszlám szellemi - tehát identitással kapcsolatos - hódító ereje gyenge. Az iszlám komoly válságban van. Nem tudja eldönteni, hogy politikai ideológia-e - azaz a hatalom megszerzésének az eszköze, mint minden ideológia -, életmód-e vagy vallás. A vallási elem, a transzcendencia gyengül, a politikai iszlám erősödik. Késekkel, robbantásokkal nem lehet sikeresen vallást terjeszteni. Régebben és más civilizációkban lehetett, de itt Európában ez nem fog múködni. Az erőszak a gyengeség jele. Ez persze nem jelenti azt, hogy az agresszióval szemben nem kell a lehető leghatározottabb és legkeményebb eszközöket alkalmazni. Ez pedig a közös kül- és védelmi politika erősítése mellett a biztonság kiemelt kezelése. A biztonsághoz tartozik a határok védelme is. Állam nincs határok nélkül, Európa sincs határok nélkül. A határokat meg kell tudni védeni. A történelem során óriási népmozgások voltak, a népvándorlás több ezer éve tart. 2015 csak egy jótékony figyelmeztető lövés volt, hogy vigyázzunk, mert ebből még nagyon nagy bajok lehetnek. A történelemben két módja volt annak, hogy egy népnek elvegyék a szállásterületét. Az egyik a háború, a másik a lassú beszivárgás. Erről itt mi, magyarok elég sokat tudnánk beszélni. A határokat tehát mindenképpen meg kell védeni.

Ha mi, európaiak rendelkezünk a saját magunk identitásával és az abba vetett hitünkkel, akkor az európai kultúra nem lehet gyengébb, mint az iszlám. Ismétlem, az iszlám erőszak és a terror a gyengeség jele. Iszlám teológusok jelentős része is abban látja a bajt, hogy engedték a vallásukból elillanni a transzcendenciát, amely pedig minden vallás lényege. A vallásnak a hitről, és nem a hatalomról, nem fegyveres hódításról kell szólnia, hanem valami másról, és ha az nincs benne, akkor lecsupaszodik, és marad valami, amit csak erôszakkal lehet terjeszteni. A terror alkalmazása nem kis mértékben az iszlámon belüli harcról szól, arról, hogy a különböző irányzatok közül melyik bizonyul a legerősebbnek, a szélsőséges politikai iszlám meg tudja-e szerezni a domináns szerepet, és vezetni tudja-e majd a többi civilizáció ellen megindítandó háborút.

Az európai kulturális örökségnek, az európai identitásnak nem része az iszlám, annak ellenére, hogy az iszlám az európai történelemben hosszú ideig jelen volt. Az európai identitás más. Más a felfogásunk mindenekelőtt a férfi és a nő kapcsolatáról is. A többnejűség önmagában azt jelenti, hogy a nő csak alacsonyabb rendű lehet. Mert hiszen, ha egy férfinak több felesége lehet, és ez fordítva kizárt, akkor teljesen világos, hogy a két nem egyelősége kizárt. Ez számunkra elfogadhatatlan. Vannak dolgok, amiket nem tudunk elfogadni és nem szabad elfogadnunk, és amit a jogrendszerünk soha nem ismerhet el. Európában nincs és nem is lesz többnejűség.

A keresztény vallás spirituális és kulturális ereje azonban csak akkor kerekedhet felül, ha ezt az erőt határozottabban megjelenítjük és az európai élet minden területén érvényesítjük. Ma már világos és egyértelmű, hogy önmagában a szekularizmus, a köztársaság egységére épülő laicitás érvényesítése nem alkalmas a politikai iszlám további térnyerésének és a párhuzamos társadalmak kialakításának a megakadályozására. Szép dolog a köztársaság eszméje, de ha erre építve egyenlő elbánásban részesítjük a zsidókeresztény örökségre épülő, az európai identitás kemény magját alkotó vallásokat és a döntően társadalmi és ideológiai célokat szolgáló, elkülönülésre és kizárólagosságra 
törekvő, a toleranciát nélkülöző, a vallások lényegét adó transzcendens tartalmat legyengítő politikai iszlámot, akkor semmilyen önmagában helyes célokra irányuló állami politika és ennek megfelelő jogalkotás nem lehet eredményes. Ha nem teszünk különbséget a keresztény vallás és kultúra évezredes jelképeinek megjelenítése és a párhuzamos iszlám világ külső jelei között és a korlátozásokat a laicitás nevében és jegyében valamennyi vallással szemben akarjuk érvényesíteni, akkor a kereszténységet a másik fél agresszív terjeszkedése következtében valójában nem egyenlő, hanem lényegesen hátrányosabb helyzetbe hozzuk.

A szekularizmusra épülő politikai és jogalkotási erőfeszítések tehát eleve kudarcra vannak ítélve, éspedig azért, mert ezek a törekvések éppen azt hagyják figyelmen kívül, ami az európai identitás és az arra épülő európai élet lényege. Ha pedig megértjük és tudomásul vesszük, hogy az európai identitás legfontosabb alkotóeleme a kereszténység, és nem felejtjük el Antall József szavait, miszerint „Európában az ateista is keresztény”, akkor érvényesítenünk kell, hogy a keresztény vallás és kultúra és a zsidó-keresztény örökség nem egy a sok közül, hanem az identitásunk, életformánk lényege, amit minden lehetséges eszközzel meg kell védenünk. A köztársasági eszme, a laicitás ehhez önmagában kevés lesz. Erősebb őrhelyekre van szükség, azokra a dómtornyokra, amelyek - mint Márai Sándor írta - összekötözik „a keresztény európai kultúra őrhelyeit”.

Az, hogy a globális rendszerben Európa demográfiailag zsugorodik, gazdaságilag teret veszít, nem jelenti azt, hogy nekünk az identitásunkat fel kell adnunk, és be kell valamibe olvadnunk. Pont ellenkezőleg! Ez a fő oka annak, hogy az európai integrációs folyamatot kellő mértékletességgel, józansággal, körültekintéssel, politikai stratégiával és taktikával, határozottabb identitással erősítenünk kell. Mi, belgák, hollandok, csehek, dánok, magyarok nem fogunk tudni ezzel a demográfiai és technológiai gyengüléssel egyedül megbirkózni. A globális rendszerből fakadó külső veszélyek, külső támadások most már nem csak Közép-Európát fenyegetik. A globális rendszerben komoly teret vesztünk, és továbbra is teret fogunk veszíteni, hogyha a saját építményünket, rendszerünket, elsősorban ennek a kulturális, szellemi energiáit és tartalékjait nem erősítjük meg.

Az európai kultúra a világban ma is nagyobb szerepet játszik, mint ami a globális GDP-ben elfoglalt helyzetéből következnék. Európának mind materiális, mind pedig szellemi, kulturális téren még mindig vannak jelentős előnyei. Európa jelenleg is a világkereskedelem legnagyobb, meghatározó szereplője. Az Európai Unió a világ első importőre és a világ első exportőre. Európa nem fogja feladni ezt a szerepét. Ami a kisugárzást illeti, az európai szellem, nem utolsósorban az európai jogi kultúra multilaterális és univerzális szinten továbbra is jelen van. Vannak tapasztalataink, tudjuk, hogyan kell összeegyeztetni egymástól eltérő fogalomrendszerek megoldásait és jogi normáit. Van tehát egy olyan integrációs tapasztalatunk, amely másoknak nincs. A mérkőzés folyik, és nem tudjuk megmondani a kimenetelét. Azt tudjuk megmondani, hogy ha a mérkőzésben eséllyel akarunk részt venni, akkor ennek érdekében mit célszerủ megtennünk.

Erősíteni kell az emberekben az európai identitást, de mindig gondoljuk meg, hogy ez milyen eszközökkel történik. Az európai polgárságot én ilyennek tartom, mert erősítheti az Európához tartozás érzését. A szabad mozgás alapvető tényező, aminek terén sok minden történt, ami még ötven-hatvan évvel ezelőtt elképzelhetetlen lett volna. Létrejött egy közös pénznem, szabadon áramlanak a szolgáltatások, a személyek, a tőke, 
az áruk, ami korábban példátlan volt. Nem mindig intézményi trükkökben, hanem tényleges eredményekben kell gondolkodnunk.

Sok olyan ötlet van, amivel a legnagyobb probléma az, hogy intézményi megoldásokat keres, intézményi téren akar újabb és újabb reformokat megvalósítani. Az emberek jelentős részének ebből elege van. Tehát nem itt kell keresni a megoldásokat.

Ami a külső veszélyeket illeti, megismétlem: az iszlám komoly kérdés, de ne higygyük, hogy erősebb vallás, világkép és világnézet, mint a mienk. Nem, a mienk az erősebb, csak ezt határozott eszközökkel érvényre kell juttatni. Azokban az országokban, ahol nagy iszlám közösség van, teljes transzparenciát, átláthatóságot kell biztosítani. Nem engedhetjük meg a vallási közösségekre épülő szeparatizmust, nem jöhetnek létre párhuzamos társadalmak. Külső hatások voltak és lesznek, mert ha nem lettek volna, akkor nem lenne Európa. De Európa mint közösség is abban érdekelt, hogy az utódaink és azok utódai a mi értékeinket, azt a Geschichtsraumot, azt a Kulturraumot, azt a Wertegemeinschaftot és azt az espace de civilisation-t őrizzék meg és vigyék tovább, ami a mi önazonosságunk lényege.

Elhangzott a Nemzeti Közszolgálati Egyetemen 2020. október 6-án. 